\title{
LITERASI PRIVASI SEBAGAI UPAYA MENCEGAH PELANGGARAN DI ERA MASYARAKAT JARINGAN
}

\author{
Kadek Aryana Dwi Putra ${ }^{1}$, Fauzan Hidayatullah ${ }^{2}$ \\ Universitas Gadjah Mada, Yogyakarta, Indonesia
}

\begin{abstract}
ABSTRAK
Penggunaan media teknologi di Indonesia berkembang sangat pesat yang dapat dilihat dari banyaknya media sosial yang bermunculan. Penggunaan media sosial yang sangat mudah dan banyak memiliki fitur menjadikan media sosial menjadi populer di era masyarakat jaringan. Pengguna yang semakin banyak menjadikan media sosial sebagai lahan bisnis yang menjanjikan bagi para pengembang media yang berbasis teknologi. Namun ketidakpahaman pengguna terhadap informasi pribadi yang dibagikan di platform media menyebabkan terjadinya pelanggaran privasi yang dilakukan untuk kepentingan pihak pengembang yang tidak bertanggung jawab. Literasi privasi menjadi langkah yang baik dalam upaya mencegah pelanggaran privasi dari sisi psikologis, fisik maupun finansial dapat di minimalkan. Sehingga pentingnya literasi privasi sebagai upaya pencegahan pelanggaran privasi di era masyarakat jejaring.
\end{abstract}

Kata-kata Kunci: literasi privasi, media sosial, masyarakat jaringan

\section{PRIVACY LITERATION AS AN EFFORT TO PREVENT BREACH IN THE NETWORK ERA}

\begin{abstract}
The use of technology media in Indonesia is developing very easily seen from the many emerging social media. Using social media is very easy and many features make social media popular in the era of network society. Users who get more make social media to get technology-based media developers. However, users' ignorance of personal information shared on media platforms causes privacy spending to be carried out in the interests of irresponsible developers. Privacy literacy is a good step in efforts to prevent privacy from the psychological side, both physical and financial that can be minimized. Related to the importance of privacy literacy as a challenge to the privacy of the network age society.
\end{abstract}

Keywords: privacy literacy, social media, community networks

\section{PENDAHULUAN}

Masyarakat di era digital menggunakan media teknologi sebagai sarana komunikasi. Penggunaan media teknologi di Indonesia berkembang sangat pesat yang dapat dilihat dari banyaknya media sosial yang bermunculan. Kemunculan media sosial menawarkan kemudahaan kepada masyarakat untuk saling terhubung satu sama lain serta saling berbagi informasi sehingga munculnya masyarakat 
jaringan. Masyarakat jaringan merupakan fenomena di era globalisasi dimana kemunculannya ditandai dengan bergulirnya revolusi industri serta berkembangnya teknologi informasi. Masyarakat jaringan merupakan masyarakat yang struktur sosial diatur oleh jaringan dan didukung oleh teknologi informasi berbasis elektronika (Castells, 2004). Masyarakat saat ini mulai mengalami perubahan dan beralih menjadi 'masyarakat virtual' yang berada pada ruang publik dengan kecanggihan media komunikasi di dalam internet. Misalnya, dalam pertukaran pendapat yang dilakukan secara tidak langsung daripada melakukannya dengan langsung tatap muka akan lebih menguras banyak waktu, dengan dibantu teknologi akan memberikan biaya yang sedikit dalam proses komunikasi.

Kemudahan dan keuntungan yang dirasakan oleh pengguna menjadikan media komunikasi menjadi popular sehingga hal ini bisa menjadi lahan bisnis yang menjanjikan bagi para pengembang media yang berbasis teknologi. Perkembangan media mengharuskan pengguna untuk menyerahkan identitas pribadi agar bisa menggunakan layanan media tersebut. Informasi yang dibagikan oleh pengguna media seperti media sosial tanpa sadar bisa dimanfaatkan oleh pihak lain. Informasi berupa identitas pribadi serta aktivitas yang dibagikan tersebut tentu dapat berisiko besar untuk disalahgunakan dan terjadi pelanggaran privasi. Informasi pribadi adalah komponen dari data privasi yang seharusnya ditutup atau dirahasiakan. Namun demikian, persoalan privasi muncul karena kurangnya pengetahuan pengguna dalam menjaga data pribadi pada media yang digunakan. Pengguna media komunikasi perlu meningkatkan literasi privasi yang memungkinkan mereka untuk memperkirakan keseimbangan antara aktivitas berbagi mereka serta kebutuhan privasi mereka.

Literasi privasi di dunia online merupakan prinsip yang digunakan untuk mendorong dan memberdayakan pengguna dalam proses pengendalian serta melindungi informasi identitas digital mereka (Wissinger \& Penn, 2017). Literasi privasi tersebut dibutuhkan terutama bagi pengguna yang rentan terhadap ancaman privasi di media komunikasi. Pada dasarnya pengguna memiliki upaya pemikiran untuk mengelola privasi mereka, namun kurangnya literasi privasi di dunia online menyebabkan pengguna sulit untuk 
berperilaku sesuai dengan sikap dan kebutuhan mereka (Trepte et al., 2015).

Berdasarkan penjelasan diatas
dapat dikatakan bahwa media
komunikasi telah memunculkan
masyarakat jejaring yang menibulkan
permasalahan privasi. Sehingga
pentingnya literasi privasi sebagai upaya
pencegahan pelanggaran privasi di era
masyarakat jejaring.

\section{METODE PENELITIAN}

Metode pada penelitian ini menggunakan penelitian kualitatif. Penelitian kualitatif digunakan dalam studi untuk memahami dan mengeksplorasi makna pada sejumlah individu dan sekelompok yang berasal dari masalah social (Creswell, 2010). Pendekatan pada penelitian ini yaitu kualitatif deskriptif. Menurut Bungin (2012) penelitian kualitatif deskriptif digunakan untuk meneliti suatu objek tertentu dengan tujuan menggambaran, pemaknaan dan melukisan secara sistematis mengenai suatu fenomena yang sedang diteliti.

Penelitian kualitatif deskriptif ini dilakukan untuk mendapatkan gambaran secara komprehensif mengenai fenomena penyalahgunan data pribadi atau data privasi di era masyarakat jaringan. Data didapatkan dari studi dokumen yang didapat literatur yang ada seperti artikel yang dipublikasikan pada jurnal ilmiah. Menurut Nilamsari (2014) sebagian besar fakta dan data sosial saat ini banyak tersimpan dalam berbentuk dokumenter sehingga ilmu-ilmu sosial serius dalam menggunakan studi dokumen menjadi teknik pengumpulan datanya.

\section{HASIL DAN PEMBAHASAN}

\section{Literasi Privasi}

Privasi dan literasi digital sering digabungkan dan dipandang setara, namun definisi keduanya berbeda. Literasi privasi merupakan pemahaman yang dimiliki konsumen tentang lanskap informasi yang berinteraksi dengan mereka dan tanggung jawab mereka dalam lanskap tersebut (Langenderfer \& Miyazaki, 2009). Definisi literasi privasi lain yaitu tingkat pemahaman dan kesadaran seseorang tentang bagaimana informasi dilacak dan digunakan dalam lingkungan online dan bagaimana informasi itu dapat mempertahankan atau kehilangan sifat privasinya (Givens, 2015). Definisi-definisi ini menyoroti gagasan literasi privasi sebagai pengalaman kognitif atau proses pemikiran yang terjadi ketika informasi dibagikan. Pemahaman literasi privasi 
ini jelas berbeda dari konsep literasi digital. Definisi literasi privasi fokus pada pemahaman tentang tanggung jawab dan risiko yang terkait dengan berbagi informasi secara online, literasi digital berfokus pada penggunaan informasi berdasarkan tugas dalam lingkungan digital. Berdasarkan definisidefinisi ini, literasi privasi lebih selaras dengan pemikiran kritis.

Berdasarkan Pasal 26 UndangUndang Nomor 11 Tahun 2008 tentang Informasi dan Transaksi Elektronik yang menyatakan bahwa penggunaan setiap data pribadi dalam sebuah media elektronik harus mendapat persetujuan pemilik data bersangkutan. Setiap orang yang melanggar ketentuan ini dapat digugat atas kerugian yang ditimbulkan. Dari pihak media sosial sebenarnya menjaga privasi penggunanya namun jika pengguna menyetujui untuk memberikan data pribadi maka data akan bisa diakses orang lain. Hal ini dapat disebabkan karena kurangnya pengetahuan pengguna tentang tata cara melindungi privasi atau kurangnya sensitifitas terhadap berbagai ancaman/ distorsi privasi.

Pengguna dengan ancaman pelanggaran privasi yaitu pengguna yang akrab dengan teknologi digital atau disebut dengan Gen C. Gen C atau connected generation merupakan gerenasi yang selalu terkoneksi dimana mereka gemar membuat konten (creation), mengkurasi konten (curation), serta membangun komunitas daring dan intens dengan aktivitas digital (connected) (Hardey, 2011). Saat ini kita sudah berada pada Gen C dimana semua masyarakat sudah terhubung dan memiliki ancaman terhadap pelanggaran privasi.

\section{Masyarakat Jaringan}

Konsep masyarakat jaringan berkaitan dengan sosial dari globalisasi dan peran teknologi komunikasi elektronik dalam masyarakat. Seorang ahli teori konsep yang paling terkenal Manuel Castells (2004) menyebutkan bahwa masyarakat jaringan merupakan masyarakat yang struktur sosialnya terdiri dari jaringan-jaringan yang ditenagai oleh teknologi informasi dan komunikasi berbasis mikro-elektronik. Seperti yang diperlihatkan Castells dalam bukunya, secara historis selalu ada jejaring sosial dengan faktor kunci yang membedakan masyarakat jejaring adalah bahwa penggunaan teknologi informasi membantu menciptakan dan mempertahankan jejaring yang jauh di mana berbagai jenis hubungan sosial baru diciptakan. Mengusung konsep 
'network society' atau 'masyarakat jaringan' Castell adalah pemikir kritis yang sudah maju pada zamannya, karena konsep tersebut masih relevan dengan kondisi saat ini dimana perkembangan teknologi informasi dan komunikasi sedemikian pesat. Masyarakat jaringan merupakan kemampuan beradaptasi dan merespon pasar global, yang terpenting adalah jaringan. Jaringan terpusat dan hierarkis yang diatur oleh perusahaan yang memberikan produk dan layanan yang efisien dan dengan harga yang menguntungkan. Keberadaan teknologi informasi dan komunikasi menjadi dimensi yang tidak dapat dipisahkan dari masyarakat. Dalam kehidupan seharihari tanpa kita sadari akan selalu bersinggungan dengan keberadaan teknologi. Berikut merupakan karakteristik masyarakat jaringan menurut Castell :

- The Network Enterprise (Jaringan Perusahaan)

Castells lebih memperhatikan perubahan dalam proses kerja dan pola kerja. Menurut Castells (2004) pekerjaan informasi telah meningkat dan lebih memuaskan daripada tenaga kerja pada masa lalu yang lebih individual.
- Cultural consequences

(Konsekuensi Budaya)

Konskuensi yang timbul karena adanya masyarakat jaringan bisa berdampak negative yang disebabkan karena adanya perubahan teknologi, seperti konten pornografi yang disimpan dalam jaringan internet. Disisi lain teknologi bisa berdampak positif, seperti pemanfaatan media pengiriman Email, namun Castell tetap menitikberatkan pada dampak negatif.

- The space of flows (Ruang arus)

Dengan informasi yang teralirkan dan tersentralisasi, tempat-tempat yang jauh dapat terintegrasi dalam jaringan internasional yang menghubungkan sektor paling dinamis. Castells menekankan bahwa kita sekarang mengalami 'diskontinuitas geografis' yang melemparkan hubungan keluar dari keteraturan.

- Timeless time

Teknologi informasi telah memusnahkan waktu, mengompresi dan juga menghilangkan peruntutan waktu, misalnya di pasar keuangan global. Timeless time mencirikan 
fungsi penguasa dan kelompok sosial.

- The power of identity (Kekuatan Identitas)

Pokok persoalan di sini adalah gerakan sosial, dimana Castells mengartikan tindakan kolektif yang mengubah nilai-nilai masyarakat yang memberikan orang dengan elemen utama identitas mereka. Misalnya, Negara terancam dengan tekanan persaingan global seperti tenaga kerja asing yang lebih murah.

- Epochal change (Era Perubahan)

Anggapan Castells bahwa kapitalisme informasi menandai perubahan dari era yg penting. Sementara kapitalisme tetap berlaku, ia percaya bahwa kita telah memasuki 'era informasi'. Castells mengacu pada 'masyarakat jaringan' sebagai konseptualisasi paling akurat dari era ini, dan sulit untuk tidak setuju dengan sebutan itu.

\section{Literasi Privasi sebagai Upaya}

Pencegahan Pelanggaran Privasi di

\section{Era Masyarakat Jaringan}

Data pribadi adalah informasiinformasi yang jika terungkap ke halayak akan dapat merugikan orang tersebut dari sisi psikologis, fisik maupun finansial. informasi seperti nama lengkap,tanggal lahir, status pernikahan, nomor induk kependudukan informasi medis, informasi tentang kontak nomor adalah privasi. Dari informasi inilah dapat diperoleh data baru yang dapat disalahgunakan untuk tujuan perdagangan dan lain sebagainya. Negara di dunia sudah menerapkan aturan khusus untuk melindungi privasi warganya dan karena aturan ini mengurus hak asasi manusia, maka biasanya cenderung ketat. Di Indonesia sudah diatur dalam Pasal 26 UndangUndang Nomor 11 Tahun 2008 tentang Informasi dan Transaksi Elektronik yang melindungi setiap data pribadi dalam sebuah media elektronik dan harus mendapat persetujuan pemilik data bersangkutan.

Di era masyarakat jaringan ini banyak bermunculan media komunikasi atau yang disebut media sosial. Jumlah media yang dibuat pengguna yang diunggah ke media sosial berkembang pesat dan melampaui kemampuan manusia mana pun untuk menyaring semua itu untuk melihat dampak media yang mana merupakan privasi (Smith \& Szongott, 2012). Salah satu masalah asasi yang sering dialami pengguna media sosial yaitu mereka tidak mau mempelajari isi dari Perjanjian Lisensi Pengguna yang diberikan media sosial. 
Di saat masalah ini muncul, pengguna biasanya justru tidak mengetahui. Misalnya pada media sosial Facebook yang dalam aturan keanggotaannya yang berisi bahwa Facebook dapat menggunakan semua informasi pengguna jika mau. Sehingga, Facebook bukan hanya tidak melanggar aturan apapun, bahkan tidak pernah melanggar hak siapapun.

Dari berbagai dampak yang ditimbulkan dari pelanggaran privasi maka dibutuhkan literasi privasi yang bisa menjadi gerbang untuk dapat menjaga data pribadi yang bersifat privasi agar penyalahgunaan tidak terjadi. Literasi privasi ini penting terutama bagi pengguna yang rentan terhadap ancaman privasi seperti di era masyarakat jaringan. Literasi privasi ini akan membantu pengguna untuk berperilaku sesuai dengan sikap dan kebutuhan mereka di dunia online.

\section{SIMPULAN}

Kemudahan dan keuntungan dengan adanya media sosial di era masyarakat jaringan sangat dirasakan oleh penggunanya dan menjadikan media komunikasi menjadi popular. Hal ini menyebabkan media sosial menjadi lahan bisnis yang menjanjikan bagi para pengembang media yang berbasis teknologi. Namun ketidakpahaman pengguna terhadap informasi pribadi yang dibagikan di platform media menyebabkan terjadinya pelanggaran privasi yang dilakukan untuk kepentingan meraup keuntungan oleh pihak yang tidak bertanggung jawab. Sehingga literasi privasi menjadi langkah yang baik dalam upaya mencegah pelanggaran privasi agar kerugian dari sisi psikologis, fisik maupun finansial dapat di minimalkan.

\section{DAFTAR PUSTAKA}

Bungin, B. (2012). Metode penelitian sosial. Jakarta: Raja Grafindo Persada.

Castells, M. (2004). Informationalism, networks, and the network society: A theoretical blueprint. In The Network Society: A Cross-Cultural Perspective (pp. 3-45). Cheltenham: Edward Elgar Publishing Limited.

Creswell, J. W. (2010). Research design: Pendekatan metode kualitatif, kuantitatif, dan campuran. Yogyakarta: Pustaka Pelajar.

Givens, C. L. (2015). Information privacy fundamentals for librarians and information professionals. In portal: Libraries and the Academy. New York: Rowman and Littlefield.

Hardey, M. (2011). Generation C: content, creation, connections and choice. International Journal of Market Research, 53(6), 749-770.

Langenderfer, J., \& Miyazaki, A. D. (2009). Privacy in the information economy. Journal of Consumer Affairs, 43(3), 380-388.

Nilamsari, N. (2014). Memahami studi dokumen dalam penelitian kualitatif. Jurnal Wacana, 13(2), 177-181. 
Smith, M., \& Szongott, C. (2012). Big data privacy issues in public social media. IEEE International Conference on Digital Ecosystems and Technologies, 1-6.

Trepte, S., Teutsch, D., Masur, P. K., Eicher, C., Fischer, M., Hennhöfer, A., \& Lind, F. (2015). Do people know about privacy and data protection strategies? towards the "Online Privacy Literacy Scale” (OPLIS).

Wissinger, C. L., \& Penn, S. (2017). Privacy literacy: From theory to practice. Communications in Information Literacy, 11(2), 378-389. 